\title{
Positive Family Atopy, Family Lifestyle and Development of Allergy Diseases
}

\author{
Helena Munivrana Skvorc ${ }^{1 *}$, Marko Skvorc ${ }^{2}$, Iva Mrkic Kobal ${ }^{3}$, Stefanija Munivrana ${ }^{4}$
}

${ }^{\mathrm{T}} \mathrm{MD}, \mathrm{PhD}$, Assistant Professor, Specialised in Pediatrics, Subspecialised in Allergology and Clinical Immunology, Children's Hospital Srebrnjak, Reference Center for Clinical Pediatric Allergology of the Ministry of Health and Social Welfare, Zagreb, Croatia

${ }^{2} \mathrm{MD}$, Specialized In Gynecology, University Hospital Zagreb-Petrova, Department of Gynaecological Oncology, Zagreb, Croatia

${ }^{3} \mathrm{MD}$, Specialised in Pediatrics, Subspecialised in Allergology and Clinical Immunology, Children's Polyclinic Dr. Sabol, Zagreb, Croatia

${ }^{4} \mathrm{MD}$, Specialised in Paediatrics, Subspecialised in Allergology and Clinical Immunolog, Pediatric Department, County Hospital Cakovec, Croatia

DOI: $10.36347 /$ sjams.2021.v09i02.008

| Received: 27.01.2021 | Accepted: 15.02.2021 | Published: 17.02.2021

*Corresponding author: Helena Munivrana Škvorc

\section{Abstract}

\section{Original Research Article}

Background: Atopic diseases are common disorders in childhood. Our aim was to estimate the association between family atopy, pet ownership, farming animals, exposure to tobacco smoke and house dust mites with development of atopic diseases. Methods: The study was undertaken among the 10-12 -year-old school children in northern Croatia (ISAAC Phase II). Results: A total of A 600 children participated in the study; of those 300 children with symptoms of allergy diseases. A total of $310(51.7 \%)$ children had a positive family atopy. We found less symptoms in children who were exposed to animals and house dust mites. Exposure to pets was significantly lower in children with positive family atopy. Conclusions: The results of our study show that risk factor for development of atopy diseases is family atopy. There were inverse relationship between animal exposure and exposure to house dust mite and development of symptoms of allergy diseases.

Keywords: Atopy; Allergy; Risk factors; Pet ownership, Farming animals, ISAAC.

Copyright $(\mathcal{O} 2021$ The Author(s): This is an open-access article distributed under the terms of the Creative Commons Attribution 4.0 International License (CC BY-NC 4.0) which permits unrestricted use, distribution, and reproduction in any medium for non-commercial use provided the original author and source are credited.

\section{INTRODUCTION}

Access to information is an essential component of development in today's globalized society.

There are uncountable internet websites and newspaper/magazine articles devoted to childhood allergy, trying to explain the risk factors for development of allergy diseases.

The increase has been rapid among children worldwide [1], especially in urban and modernized regions of the world, suggesting that environmental factors seem to be major determinants for this increase [2]. As far as genetic factors are concerned, a family atopy is considered to increase the risk of allergy development [3]. Regarding some environmental factors, results are controversial [4-7].

Modern parents are more aware of important role of numerous environmental factors in relation to atopy, so they may change their lifestyle in an attempt to prevent allergy in their children, especially in families with positive family atopy. This causes differences in exposure to protective and risk factors in early childhood between children with positive and negative family atopy [8].

The aim of the present study was to estimate the association between family atopy, pet ownership, farming animals, exposure to tobacco smoke and house dust mites with development of asthma, allergic rhinitis/rhinoconjuctivitis and atopic eczema symptoms in the Medjimurje-Cakovec County in Northwest Croatia.

\section{Material ANd Methods}

The study was undertaken among the 10-12 year-old school children in the Međimurje region in northern Croatia. Data were collected using standardized ISAAC written questionnaire phase II completed by parents. A full description of the ISAAC study protocol was published previously [9]. All standardized modules were translated from English to Croatian by physicians specializing in asthma and 
Helena Munivrana Skvorc et al; Sch J App Med Sci, Feb, 2021; 9(2): 212-216

allergy [10], according to translation guidelines [11]. The correctness of the questionnaire was tested by back-translation by an independent professional translator. Ethical approval was obtained from the local ethics committee before the start of the study. Any inconsistencies found were eliminated in a phone conversation with the parents. Data were then entered into a computer and analyzed. Statistical analyses were performed using IBM SPSS Statistics version 19.0.0.1. Basic descriptive summaries of the data were obtained and differences between investigated groups were calculated with cross-tabulation and the chi-square test. A $\mathrm{P}<0.05$ indicated a statistically significant difference.

We collected data about family atopy, exposure to pets and farming animals, exposure to tobacco smoke, sleeping on feather pillow, sleeping on mattress older than 3 years, and having carpets in the child's bedroom.

Exposure to indoor and outdoor pets was documented separately for cats, dogs, rodents and birds. Exposure to farming animals was documented separately for chickens, pigs, cows, horses and rabbits.

The data on exposure to environmental factors and family atopy were than related to allergic symptoms.

\section{RESULTS}

A total of 600 children participated in the study; of those 300 children with symptoms of allergy diseases. The children were aged 10 years 0 months to 12 years 11 months (10-year-olds: $\mathrm{n}=198$ (33.0\%), 11year-olds: $n=204 \quad(34.0 \%), \quad 12$-year-olds: $n=198$ $(33.0 \%)$ ), of those $366(61.0 \%)$ were boys. Of the children with symptoms of allergy diseases, 114 $(38.0 \%)$ reported wheezing, $247(81,0 \%)$ reported allergic rhinitis and $59(19,7 \%)$ reported atopic dermatitis in the last 12 months. In both groups, 222 $(37 \%)$ children reported wheeze ever.

A total of $310(51.7 \%)$ children had a positive family atopy, with significant difference between children with symptoms $(31.8 \%)$ and without symptoms (19.8\%) of allergy diseases (OR: 2,6653, 95\% CI: 1,9162-3,7071, $\mathrm{P}<0,0001)$.
Table- 1 shows the animal exposure in $1^{\text {st }}$ year of life $(\%)$, from $2^{\text {nd }}$ to $7^{\text {th }}$ year of life $(\%)$ and after $7^{\text {th }}$ year of life $(\%)$ for children with and without symptoms of allergy diseases.

In first year of life we found less symptoms of allergy diseases in children who were exposed to cats (indoor: $\chi 2=5,79, \mathrm{P}=0,05508$; outdoor: $\chi 2=7,22$, $\mathrm{P}=0,02703$ ) and dogs (outdoor: $\chi 2=6,57, \mathrm{P}=0,03740$ ). Exposure to pets from $2^{\text {nd }}$ to $7^{\text {th }}$ year of life and less symptoms were found in children exposed to indoor pets: cats $(\chi 2=6,45, \mathrm{P}=0,03975)$ and $\operatorname{dogs}(\chi 2=8,25$, $\mathrm{P}=0,01613)$. Exposure to pets after age of 7 years and less allergic symptoms is only seen in exposure to indoor dogs $(\chi 2=12,82, \mathrm{P}=0,00165)$. We did not found any difference in allergic symptoms in children exposed to rodents and birds.

Exposure to farming animals and less allergic symptoms were found in children who were exposed to chickens $(\chi 2=5,90, \mathrm{P}=0,05228)$ and pigs $(\chi 2=7,08$, $\mathrm{P}=0,02898)$ in first year of life, pigs from age 2 to 7 year $(\chi 2=12,93, \mathrm{P}=0,00156)$, pigs $(\chi 2=7,83, \mathrm{P}=0,01991)$ and horses $(\chi 2=8,41, \mathrm{P}=0,01493)$ after age of 7 years.

Exposure to pets was significantly lower in children with positive family atopy (OR: 0,6159, 95\% CI: $0,3818-0,9937, P=0,0466)$, especially in the first year of life (OR: 0,5498, 95\% CI: 0,3088-0,9789, P = $0,0417)$. Exposure to pets from $2^{\text {nd }}$ to $7^{\text {th }}$ year of life was also lower, but these difference was not significant (OR: 0,9796, 95\% CI: 0,7349-1,3058, P = 0,8881).

We did not found statistically significant difference in exposure to farming animals with positive family atopy.

Exposure to tobacco smoke during the pregnancy and in childhood is shown in Table 2 . We did not found any difference in allergic symptoms in children exposed to tobacco smoke.

Less allergic symptoms were found in children who were sleeping on feather pilow $(\chi 2=24,445$, $\mathrm{P}<0,0001)$ and mattress older than 3 years $(\chi 2=16,228$, $\mathrm{P}<0,0001$ ) after age of 7 (Table 2).

Less allergic symptoms were found in children who had carpets in bedrooms after age of $7(\chi 2=8,224$, $\mathrm{P}=0,016$ ) (Table-2). 
Helena Munivrana Skvorc et al; Sch J App Med Sci, Feb, 2021; 9(2): 212-216

Table-1: Animal exposure in $1^{\text {st }}$ year of life (\%), from $2^{\text {nd }}$ to $7^{\text {th }}$ year of life $(\%)$ and after $7^{\text {th }}$ year of life (\%) for children with $(\mathrm{N}=300)$ and without $(\mathrm{N}=300)$ symptoms of allergy diseases

\begin{tabular}{|c|c|c|c|c|c|c|c|c|c|}
\hline \multirow{2}{*}{$\begin{array}{l}\text { Animal } \\
\text { exposure }\end{array}$} & \multicolumn{3}{|c|}{ In $1^{\text {st }}$ year of life (\%) } & \multicolumn{3}{|c|}{ From $2^{\text {nd }}$ to $7^{\text {th }}$ year of life $(\%)$} & \multicolumn{3}{|c|}{ After $7^{\text {th }}$ year of life (\%) } \\
\hline & $\begin{array}{l}\text { With } \\
\text { sypmtoms }\end{array}$ & Healthy & $\mathrm{P}$ & $\begin{array}{l}\text { With } \\
\text { sypmtoms }\end{array}$ & Healthy & $\mathrm{P}$ & $\begin{array}{l}\text { With } \\
\text { sypmtoms }\end{array}$ & Healthy & $\mathrm{P}$ \\
\hline Dogs - indoor & 3 & 6,7 & 0,109 & 8 & 15,3 & 0,016 & 8,7 & 18 & $\mathbf{0 , 0 0 2}$ \\
\hline Dogs - outdoor & 9,3 & 16,3 & $\mathbf{0 , 0 3 7}$ & 53,7 & 52 & 0,328 & 57,7 & 51,7 & 0,163 \\
\hline Cats - indoor & 6 & 11 & 0,055 & 16 & 22,3 & 0,040 & 16,3 & 23,3 & 0,097 \\
\hline Cats - outdoor & 8 & 15 & $\mathbf{0 , 0 2 7}$ & 44,3 & 50,3 & 0,180 & 47 & 48,3 & 0,717 \\
\hline Rodents - indoor & 0,7 & 0,7 & 0,513 & 4 & 3,3 & 0,816 & 4,7 & 6,7 & 0,553 \\
\hline $\begin{array}{l}\text { Rodents } \\
\text { outdoor }\end{array}$ & 0,3 & 1 & 0,316 & 2 & 3 & 0,702 & 3,7 & 5,7 & 0,509 \\
\hline Birds - indoor & 1,7 & 5 & 0,075 & 7,3 & 8,7 & 0,768 & 6,3 & 6,7 & 0,211 \\
\hline Birds - outdoor & 2,3 & 3 & 0,816 & 6,3 & 6,7 & 0,930 & 5,3 & 4 & 0,483 \\
\hline Chickens & 4,3 & 9,3 & 0,052 & 29,7 & 37 & 0,114 & 25,3 & 32,3 & 0,149 \\
\hline Pigs & 0 & 2,3 & $\mathbf{0 , 0 2 9}$ & 13,3 & 21,7 & 0,002 & 12,7 & 18,7 & 0,020 \\
\hline Cows & 0,3 & 1,3 & 0,365 & 4 & 6,7 & 0,096 & 3,7 & 5,3 & 0,391 \\
\hline Horses & 0,3 & 0,3 & 1,000 & 1,3 & 3 & 0,161 & 1,7 & 5,3 & 0,015 \\
\hline Rabbits & 1 & 1,7 & 0,714 & 11 & 16 & 0,198 & 12,3 & 16 & 0,299 \\
\hline
\end{tabular}

Table-2: Exposure to risk factors in children with $(\mathrm{N}=300)$ and without $(\mathrm{N}=300)$ symptoms of allergy diseases $(\%)$

\begin{tabular}{|c|c|c|c|c|}
\hline & With symptoms (\%) & Healthy (\%) & $\mathbf{X}^{2}$ & $\mathbf{P}$ \\
\hline $\begin{array}{l}\text { Exposure to tobacco smoke } \\
\text { During the pregnancy } \\
\text { During the childhood } \\
1^{\text {st }} \text { year of life } \\
2^{\text {nd }}-7^{\text {th }} \text { year of life } \\
>7^{\text {th }} \text { year of life }\end{array}$ & $\begin{array}{l}23.7 \\
38 \\
30.3 \\
35.7 \\
31.7\end{array}$ & $\begin{array}{l}24 \\
33 \\
26.7 \\
31 \\
30\end{array}$ & $\begin{array}{l}0.015 \\
1.638 \\
0.992 \\
1.483 \\
0.501 \\
\end{array}$ & $\begin{array}{l}0.993 \\
0.201 \\
0.609 \\
0.476 \\
0.778 \\
\end{array}$ \\
\hline $\begin{array}{l}\text { Sleeping on feather pilow } \\
1^{\text {st }} \text { year of life } \\
2^{\text {nd }}-7^{\text {th }} \text { year of life } \\
>7^{\text {th }} \text { year of life }\end{array}$ & $\begin{array}{l}45.7 \\
15.4 \\
38.3 \\
10.6\end{array}$ & $\begin{array}{l}50.7 \\
18 \\
42.0 \\
26.4\end{array}$ & $\begin{array}{l}1.502 \\
0.776 \\
1.376 \\
24.445\end{array}$ & $\begin{array}{l}0.220 \\
0.678 \\
0.503 \\
<0,0001\end{array}$ \\
\hline $\begin{array}{l}\text { Sleeping on mattress older than } 3 \text { years } \\
1^{\text {st }} \text { year of life } \\
2^{\text {nd }}-7^{\text {th }} \text { year of life } \\
>7^{\text {th }} \text { year of life }\end{array}$ & $\begin{array}{l}19.0 \\
31.0 \\
36.0 \\
\end{array}$ & $\begin{array}{l}15.0 \\
37.0 \\
52.3 \\
\end{array}$ & $\begin{array}{l}1.701 \\
2.406 \\
16.228 \\
\end{array}$ & $\begin{array}{l}0.192 \\
0.121 \\
<0.0001 \\
\end{array}$ \\
\hline $\begin{array}{l}\text { Carpets in child's bedroom } \\
1^{\text {st }} \text { year of life } \\
2^{\text {nd }}-7^{\text {th }} \text { year of life } \\
>7^{\text {th }} \text { year of life }\end{array}$ & $\begin{array}{l}59.3 \\
65.0 \\
40.0\end{array}$ & $\begin{array}{l}56.0 \\
62.0 \\
51.7 \\
\end{array}$ & $\begin{array}{l}0.683 \\
1.235 \\
8.224 \\
\end{array}$ & $\begin{array}{l}0.711 \\
0.539 \\
0.016 \\
\end{array}$ \\
\hline
\end{tabular}

\section{DISCUSSION}

The present study was carried out using the ISAAC international methodology for the prevalence rates and risk factors for the development of atopic diseases. Environmental factors seem to be major determinants for this increase [2]. As far as genetic factors are concerned, a family atopy is considered to increase the risk of allergy development [3]. Regarding some environmental factors, results are controversial [47].

Our results are consistent with the hypothesis that positive family atopy increases the risk of atopy diseases $[12,13]$.

Despite the number of studies, results about exposure to pets and development of atopy diseases are controversial $[14,15]$. In our study exposure to pets during childhood was linked to reduced allergy risk. Previous studies have demonstrated that dogs alter the home microbiota $[16,17]$ and that microbes associated with dogs can reduce allergic airway inflammation and bronchial reactivity in mouse models [18].

Exposure to pets after the first year of age is more often in healthy population than in those with allergic symptoms. This could suggest a protective role of long-term animal exposure on development of atopy diseases or could be explained by selective avoidance of keeping pets in atopic children.

Exposure to farming animals reduce the risk of development of atopy diseases. Our results are consistent with many studies which can be explained by environmental exposure to endotoxin levels [19].

Early exposure to second-hand smoking has been shown to be associated with the development of atopy diseases [20, 21]. However, there are also studies showing no association between exposure to secondhand tobacco smoke and atopy diseases [22]. In our study, exposure to maternal smoking during pregnancy 
and exposure to environmental tobacco smoke was not connected to the symptoms of atopy diseases.

Important role in development of asthma, allergic rhinitis and atopic dermatitis has exposition to Dermatophagoides pteronyssinus and Dermatophagoides farina which are present in mattresses, carpets, duvets/pillows and upholstered furniture [23].

Feather pillows accumulate a high concentration of dust [24] and children sleeping on them are more likely to be exposed to inhalation allergens like dust mites, which possibly leads to an increased risk for early sensitisation and development of atopy diseases [25].

Our results show that less allergic symptoms were found in children who were sleeping on feather pillow and mattress older than 3 years after age of 7 . Less allergic symptoms were found in children who had carpets in bedrooms after age of 7 . These results can be explained by measures of primary and secondary prevention and good education of parents. Also protective effect cannot be excluded which can be explained by environmental exposure to endotoxin levels [19].

\section{CONCLUSion}

The results of our study show that risk factor for development of atopy diseases is family atopy, There were inverse relationship between animal exposure and exposure to house dust mite and development of symptoms of allergy diseases. However, much of this protective effect could be explained by selective avoidance of keeping pets and elimination of house dust mites. Because of controversial results of previous studies conducted on the same topic, further investigations should be made.

ACKNOWLEDGMENTS: The authors would like to thank all the teachers, parents, and children who participated in this study.

\section{REFERENCES}

1. Downs SH, Marks GB, Sporik R, Belosouva EG, Car NG, Peat JK. Continued increase in the prevalence of asthma and atopy. Arch Dis Child. 2001;84:20-23.

2. von Mutius E. Influences in allergy: epidemiology and the environment. J Allergy Clin Immunol. 2004;113:373-9; quiz 380.

3. Jaakkola JJ, Hwang BF, Jaakkola N. Home dampness and molds, parental atopy, and asthma in childhood: a six-year population-based cohort study. Environ Health Perspect. 2005 Mar;113(3):357-61.
4. Hesselmar B, Aberg N, Aberg B, Eriksson B, Björkstén B. Does early exposure to cat or dog protect against later allergy development? Clin Exp Allergy. 1999 May;29(5):611-7.

5. Pohlabeln H, Jacobs S, Böhmann J. Exposure to pets and the risk of allergic symptoms during the first 2 years of life. J Investig Allergol Clin Immunol. 2007;17(5):302-8.

6. Riedler J, Braun-Fahrländer C, Eder W, Schreuer M, Waser M, Maisch S, Carr D, Schierl R, Nowak D, von Mutius E; ALEX Study Team. Exposure to farming in early life and development of asthma and allergy: a cross-sectional survey. Lancet. 2001 Oct 6;358(9288):1129-33.

7. Remes ST, Koskela HO, Iivanainen K, Pekkanen J. Allergen-specific sensitization in asthma and allergic diseases in children: the study on farmers' and non-farmers' children. Clin Exp Allergy. 2005 Feb;35(2):160-6.

8. Schayck CP, Knottnerus JA. Can the 'hygiene hypothesis' be explained by confounding by behaviour? J Clin Epidemiol. 2004;57:435-7.

9. Asher MI, Keil U, Anderson HR, Beasley R, Crane J, Martinez F, et al. International Study of Asthma and Allergies in Childhood (ISAAC): rationale and methods. Eur Respir J. 1995;8:483491.

10. Banac S, Tomulic KL, Ahel V, Rozmanic V, Simundic N, Zubovic S, Milardovic A, Topic J. Prevalence of asthma and allergic diseases in Croatian children is increasing: survey study. Croat Med J, 2004; 45(6): 721-26.

11. Weiland SK, Beasley R, Strachan D: Guidelines for the translation of questionnaires. Munster, Germany: ISAAC Phase One Coordinating Committee, 1993.

12. Lee YL, Li CW, Sung FC, Yu HS, Sheu HM, Guo YL. Environmental factors, parental atopy and atopic eczema in primary-school children: a crosssectional study in Taiwan. $\mathrm{Br} \mathrm{J}$ Dermatol. 2007; 157:1217-24.

13. Wen HJ, Chen PC, Chiang TL, Lin SJ, Chuang YL, Guo YL. Predicting risk for early infantile atopic dermatitis by hereditary and environmental factors. Br J Dermatol. 2009;161: 1166-72.

14. Hesselmar B, Aberg N, Aberg B, Eriksson B, Björkstén B. Does early exposure to cat or dog protect against later allergy development? Clin Exp Allergy. 1999;29:611-7.

15. Pohlabeln H, Jacobs S, Böhmann J. Exposure to pets and the risk of allergic symptoms during the first 2 years of life. J Investig Allergol Clin Immunol. 2007; 17:302-8.

16. Fujimura KE, Johnson CC, Ownby DR, et al. Man's best friend? The effect of pet ownership on house dust microbial communities. J Allergy ClinImmunol. 2010;126:410-2.

17. Dunn RR, Fierer N, Henley JB, Leff JW, Menninger HL. Home life: factors structuring the 
bacterial diversity found within and between homes. PLoS One. 2013;8:e64133.

18. Fujimura KE, Demoor T, Rauch M, Faruqi AA, Jang S, Johnson CC, Boushey HA, Zoratti E, Ownby D, Lukacs NW, Lynch SV. House dust exposure mediates gut microbiome Lactobacillus enrichment and airway immune defense against allergens and virus infection. Proc Natl Acad Sci USA. 2014;111:805-10.

19. Braun-Fahrlander C, Riedler J, Herz U, Eder W, Waser M, Grize L, Maisch S, Carr D, Gerlach F, Bufe A, Lauener RP, Schier R, Renz H, Nowak D, von Mutius E, Allergy and Endotoxin Study Team . Environmental exposure to endotoxin and its relation to asthma in school-age children. N Engl J Med. 2002; 347:869-77

20. Kramer U, Lemmen CH, Behrendt H, Behrendt H, Link E, Schäfer T, Gostomzyk J, Scherer G, Ring J.. The effect of environmental tobacco smoke on eczema and allergic sensitization in children. $\mathrm{Br} \mathbf{J}$ Dermatol. 2004;150:111-8.

21. Tanaka K, Miyake Y, Sasaki S, Ohya Y, Hirota Y. Maternal smoking and environmental tobacco smoke exposure and the risk of allergic diseases in Japanese infants: the Osaka Maternal and Child Health Study. J Asthma. 2008; 45: 833-8.

22. Strachan DP, Cook DG. Health effects of passive smoking: 5. Parental smoking and allergic sensitisation in children. Thorax. 1998; 53: 117 23.

23. Sidenius KE, Hallas TE, Brygge T, Poulsen LK, Mosbech H. House dust mites and their allergens at selected locations in the homes of house dust mite-allergic patients. Clin Exp Allergy 2002; 32:1299-304.

24. Sidenius KE, Hallas TE, Brygge T, Poulsen LK, Mosbech H. House dust mites and their allergens at selected locations in the homes of house dust mite-allergic patients. Clin Exp Allergy. 2002;32: 1299-304.

25. Pajno GB, Peroni DG, Barberio G, Pietrobelli A, Bones AL. Predictive features for persistence of atopic dermatitis in children. Pediatr Allergy Immunol. 2003;14: 292-5. 